\title{
Swarm characteristics of Antarctic krill Euphausia superba relative to the proximity of land during summer in the Scotia Sea
}

\author{
T. A. Klevjer ${ }^{1, *}$, G. A. Tarling ${ }^{2}$, S. Fielding ${ }^{2}$ \\ ${ }^{1}$ Department of Biology, University of Oslo, PO Box 1064, Blindern, 01316 Oslo, Norway \\ ${ }^{2}$ British Antarctic Survey, Natural Environment Research Council, High Cross, Madingley Rd, Cambridge CB3 0ET, UK
}

\begin{abstract}
We studied the relationship between the proximity of land and the distribution and swarming characteristics of Antarctic krill across the Scotia Sea in January and February 2003. Krill swarms identified with a Simrad EK60 $(38 \mathrm{kHz}, 120 \mathrm{kHz})$ echosounder were grouped into 4 categories according to distance from shoreline: 0 to $50 \mathrm{~km}, 50$ to $100 \mathrm{~km}, 100$ to $200 \mathrm{~km}$ and $>200 \mathrm{~km}$. Cross-sectional areas of swarms were significantly larger inshore, with a mean value of $120 \mathrm{~m}^{2}$ in the 0 to $50 \mathrm{~km}$ zone compared to $<80 \mathrm{~m}^{2}$ further offshore. The packing concentration of krill within inshore swarms was also significantly greater, with an average density of $95 \mathrm{ind} . \mathrm{m}^{-3}$ compared to between 24 and 31 ind. $\mathrm{m}^{-3}$ elsewhere. A large proportion of the biomass was concentrated into a small number of large, dense swarms throughout the survey area, and this trend increased with decreasing distance from shore. The highest median number of swarms per $\mathrm{km}$ and krill acoustic biomass per $\mathrm{km}$ was found in the 50 to $100 \mathrm{~km}$ zone. However, a significantly greater number of large, biomass-rich swarms occurred in the 0 to $50 \mathrm{~km}$ zone compared to all other zones. Swarms in the 0 to $50 \mathrm{~km}$ zone were also significantly further apart. The majority of swarms were located in the upper $50 \mathrm{~m}$ during the daytime although they were marginally deeper in the night in offshore regions. Krill are likely to move between inshore and offshore environments continuously over their lifetimes. The change in krill behaviour between environments could be a response to local predatory threats over short spatial and temporal scales.
\end{abstract}

KEY WORDS: Acoustics - Southern Ocean - Distribution - Vertical migration - Predation - Seals · Penguins · Fishery

Resale or republication not permitted without written consent of the publisher

\section{INTRODUCTION}

The pattern of swarming by krill has a strong influence on the distribution of their predators (Veit et al. 1993). Birds and mammals frequently aggregate where dense aggregations of krill are predictable and sustained (Croll et al. 1998) and especially large krill patches can have a disproportionate influence on the distribution of predators (Heinemann et al. 1989). Foraging often begins only when detected krill aggregations are above a threshold density (Zamon et al. 1996) although predators adjust their foraging behaviour in response to variability in krill density and distribution
(Mori \& Boyd 2004). A thorough appreciation of the nature of patchiness in the krill prey field is an essential step to interpreting foraging behaviour in krill predators (Hunt et al. 1992).

There are both costs and benefits to swarming (Ritz 1994). It can assist in the location of food (Antezana \& Ray 1983) or mates (Nicol 1984), decrease the individual cost of swimming through collective slipstreaming (Ritz 2000) and provide protection from predators (O'Brien 1987). However, the absolute numbers of krill in large swarms creates an internal microenvironment of waste products, reduced $\mathrm{O}_{2}$, parasites, disease and lack of food (Hamner \& Hamner 2000). Greatest atten- 
tion has been given to the protective benefits of swarming and there are numerous case studies of the interaction between predators and swarms (O'Brien 1987, Zhou \& Dorland 2004, Cox et al. 2009).

Swarming is not the only means of reducing the threat of predation. Vertical migration to deeper parts of the water column also reduces risk, particularly in relation to surface-diving predators such as penguins and seals. The deeper layers are also darker, which reduces the visual acuity of both diving predators and planktivorous fish (e.g. mackerel icefish) and inhibits their ability to locate and capture prey (Aksnes \& Giske 1993). Nevertheless, krill must occupy the surface layers for certain periods in order to feed, which cannot always be under the cover of darkness during the polar summer.

There is a great deal of interaction between the strong advective forces within the Southern Ocean and the life cycle of Antarctic krill (Nicol 2006). This is likely to result in krill travelling great distances during their lifetime (Thorpe et al. 2004, 2007). This journey will probably traverse both inshore and offshore environments (Atkinson et al. 2008) and will also involve interactions with seasonal sea-ice (Murphy et al. 2007). As well as being driven by the currents, Antarctic krill may also actively migrate between inshore and offshore environments at various stages of their life cycle, possibly in response to food availability or reproductive condition (Siegel 2000). Therefore, the stocks of krill in inshore and offshore environments are likely to be regularly mixed. This further implies that any difference in swarming behaviour and distribution between these environments probably reflects shortterm responses by krill to local conditions.

The predatory impact of land-based predators on krill biomass can be large. Annual prey requirements of Antarctic fur seals and macaroni penguins on South Georgia alone are in the order of $11.9 \mathrm{Mt}$ (range of 6.4 to $17.5 \mathrm{Mt}$, Boyd 2002). Recent published estimates of krill standing stock for the Scotia Sea (including South Georgia) range between 36 and 44 million tonnes (Trathan et al. 1995, Hewitt et al. 2004). The highest abundances of these predators are found between 60 to $120 \mathrm{~km}$ from land and decrease sharply at distances greater than $150 \mathrm{~km}$ from land (Reid et al. 2004). Therefore, it is likely that the nature of interactions between krill and its predators changes considerably moving away from land over small scales $(<100 \mathrm{~km})$.

A further dynamic element is the potential impact of harvesting by krill fisheries. These operate at a scale of $150 \mathrm{~km}$ and occur almost entirely within $100 \mathrm{~km}$ of land (Reid et al. 2004). Commercial harvests of krill aggregations have the potential to affect local availability to krill predators. This is of particular concern to the Commission for the Conservation of Antarctic
Marine Living Resources (CCAMLR), which manages the krill fishery and must balance the exploitation of the krill catch against the demands of the wider ecosystem, especially krill-dependent predator species. Identifying how krill biomass is distributed between swarms and the relative importance of different swarm types to fishery vessels and foraging predators is an aspect yet to be fully considered within the current management approach.

Recently, Tarling et al. (2009) categorised swarms into different types based on 7 swarm properties (depth, length, thickness, area, packing concentration, swarm acoustic biomass and distance to next swarm). Two main types of swarm were distinguished and the contribution each type made to the krill population was found to vary across the survey region. The survey covered a large area of the Scotia Sea, and included a number of areas where the fishery presently operates. The study also found that variation in swarm type distribution was predictable as a function of the body size and maturity of krill, the ambient level of fluorescence and level of light. Distance from land was not identified as a strong predictor of swarm type. However, the study focussed on mesoscale patterns (100 to $1000 \mathrm{~km}$ ) whereas inshore-offshore clines are probably best resolved at smaller scales (1 to $100 \mathrm{~km}$ ).

The intention of the present study is to describe krill swarming patterns and biomass in relation to one of the most important variables to a land-based predator, the distance it must travel from shore in order to reach its resource. This will enhance the interpretation of observed foraging patterns of krill-dependent predators such as seals and penguins. It will also provide valuable parameterisations, especially for models predicting optimal foraging patterns in krill predators. The results are also of direct relevance to the management of fisheries in this region, particularly in examining the relationship between swarm-biomass distribution patterns and fishing effort. Although it is accepted that distance from shore is only one of many influences on the swarming behaviour in krill, our observations of swarm features that alter along this cline provide some interesting insights into the behavioural ecology of krill.

\section{MATERIALS AND METHODS}

General survey details. The RRS 'James Clark Ross' undertook a survey (JR82) between 9 January and 16 February 2003 involving 8 transects within the region $65^{\circ} \mathrm{S}$ to $50^{\circ} \mathrm{S}$ and $30^{\circ} \mathrm{W}$ to $55^{\circ} \mathrm{W}$ in the Scotia Sea (Fig. 1). The survey area covered continental shelves, oceanic regions and major frontal zones. The majority of transects were transited at speeds between 5 and 10 knots (except for ice) with a ping rate of 1 to 


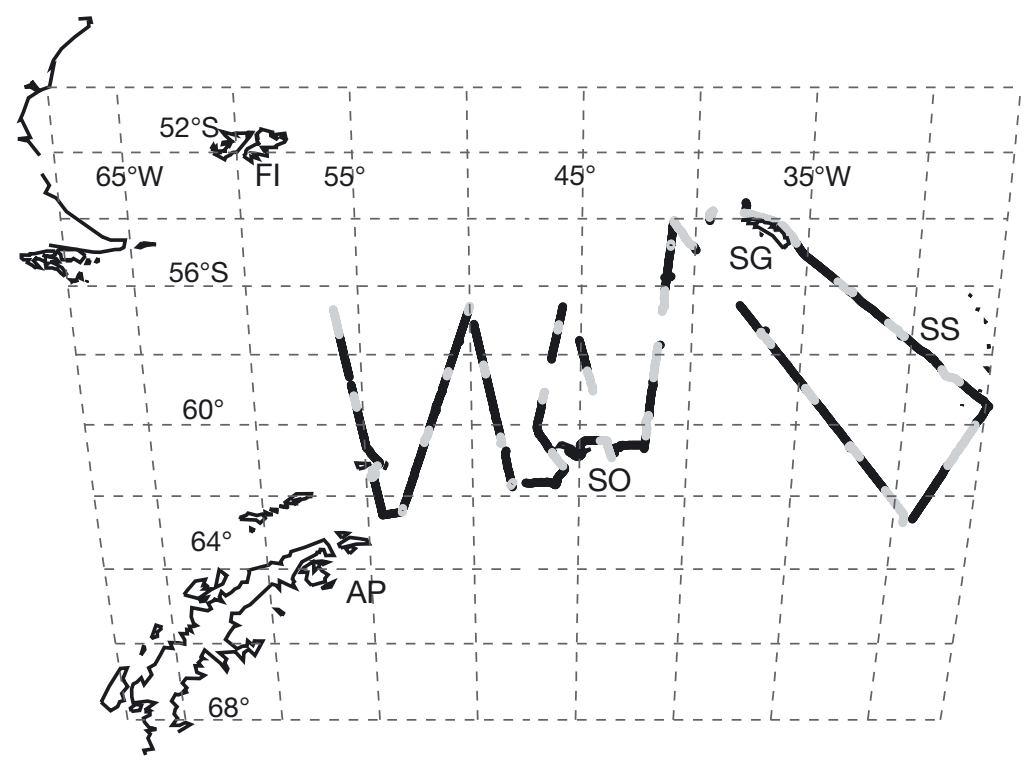

Fig. 1. Survey track highlighting the periods when acoustics were active and collecting acoustic data of sufficient analytical quality. Daytime sampling is indicated by black lines, night-time sampling by grey lines. FI: Falkland Islands, AP: Antarctic Peninsula, SO: South Orkney Islands, SG: South Georgia, SS: South Sandwich Islands

$1.5 \mathrm{~s}$ and a pulse length of $1024 \mu \mathrm{s}$. Krill were sampled either at fixed stations 60 nautical miles (n mile) apart, or en route, depending on when suitable swarms were located, using a rectangular midwater trawl (RMT8). Further details on net sampling strategy are given in Tarling et al. (2009)

Acoustic data. Volume backscattering strength $\left(\mathrm{S}_{\mathrm{v}}\right.$ re. $\left.1 \mathrm{~m}^{-1}, \mathrm{~dB}\right)$ was collected using a SIMRAD EK60 echosounder with hull-mounted split-beam $38 \mathrm{kHz}$, $120 \mathrm{kHz}$ and $200 \mathrm{kHz}$ transducers. Acoustic system calibrations were undertaken at Stromness Bay (54 ${ }^{\circ} 9.44^{\prime} \mathrm{S} 36^{\circ} 41.99^{\prime} \mathrm{W}$ on 17 February 2003), using the standard sphere method (Foote et al. 1987).

Acoustic processing. The raw acoustic data from the $38 \mathrm{kHz}$ and $120 \mathrm{kHz}$ sounders were processed using Sonardata Echoview v. 4.0. Filters were applied to exclude the surface-most $13 \mathrm{~m}$ and depths below the detected bottom (where applicable) and other 'bad data' resulting from interference or bad weather. Background noise levels were estimated and subtracted from both the $38 \mathrm{kHz}$ and $120 \mathrm{kHz}$ echograms using the method of Watkins \& Brierley (1996). Smaller spikes were removed from the data by restricting the final swarm detection to those regions of the echogram where the $7 \times 7$ (pings $\times$ samples, where the ping interval was $1.5 \mathrm{~s}$ and sample length $0.1867 \mathrm{~m}$ ) convolution filtered data were above a threshold of $-80 \mathrm{~dB}$ at $120 \mathrm{kHz}$. Subsequent analyses showed that this filter did not exclude any swarms delineated by the detection algorithms described in the next paragraph ('Swarm detection'). The $\mathrm{S}_{\mathrm{v}}$ threshold used in the final swarm detection was $-70 \mathrm{~dB}$ at $120 \mathrm{kHz}$, as advised by Lawson et al. (2008a) based on estimates of the maximum distance that individual krill can remain in visual contact with each other. With a ping interval of $1.5 \mathrm{~s}$ and a standard cruising speed of 10 knots, the minimum spatial resolution was $7.5 \mathrm{~m}$. There was some variation in each of these parameters depending on ice conditions and bathymetry.

Swarm detection: A swarm detection algorithm was applied to the $120 \mathrm{kHz}$ echogram data using Sonardata Echoview 4.0 'School detection module', which employs a SHAPES algorithm (Coetzee 2000). The software was set to detect swarms with a minimum length of $15 \mathrm{~m}$ and thickness of $2 \mathrm{~m}$ (Table 1). Swarms were linked if they were $<15 \mathrm{~m}$ apart horizontally or $5 \mathrm{~m}$ apart vertically. These parameters were selected partially to match the resolution offered by our acoustic data, and partially by reference to settings used in previous studies of Antarctic krill and results obtained therein (Miller \& Hampton 1989a,b, Sprong \& Schalk 1992, Miller et al. 1993, Watkins \& Brierley 2002, Woodd-Walker et al. 2003, Lawson et al. 2008b). Further details on the sensitivity of swarm detection to parameter and threshold settings are detailed in Tarling et al. (2009).

Table 1. Transducer specifications during cruise JR82 and pre-detection and swarm detection settings. Further settings and constants are given in Tarling et al. (2009). $\mathrm{S}_{\mathrm{v}}$ : volume backscattering strength, $\mathrm{S}_{\mathrm{a}}$ : correction coefficient

\begin{tabular}{|c|c|c|}
\hline Specification & $\begin{array}{l}38 \mathrm{kHz} \\
\text { transducer }\end{array}$ & $\begin{array}{c}120 \mathrm{kHz} \\
\text { transducer }\end{array}$ \\
\hline Transducer type & ES38 & ES120-7 \\
\hline Transducer depth (m) & 5.00 & 5.00 \\
\hline Max. power (W) & 2000 & 1000 \\
\hline Pulse duration (ms) & 1.024 & 1.024 \\
\hline Ping rate $\left(\mathrm{s}^{-1}\right)$ & $1-1.5$ & $1-1.5$ \\
\hline Absorption coefficient $\left(\mathrm{dB} \mathrm{km}^{-1}\right)$ & 10.09 & 27.69 \\
\hline Transducer gain $(\mathrm{dB})$ & 24.19 & 22.43 \\
\hline $\mathrm{S}_{\mathrm{a}}$ correction & -0.06 & -0.42 \\
\hline Setting & \multicolumn{2}{|c|}{$120 \mathrm{kHz}$ value } \\
\hline Surface exclusion zone (m) & \multicolumn{2}{|c|}{$\geq 13$} \\
\hline Maximum permitted data range $(\mathrm{m})$ & \multicolumn{2}{|c|}{300 or sea bottom } \\
\hline $\mathrm{S}_{\mathrm{v}}$ threshold $(\mathrm{dB})$ & \multicolumn{2}{|c|}{-70} \\
\hline Min. horizontal candidate (m) & \multicolumn{2}{|r|}{10} \\
\hline Min. vertical candidate (m) & \multicolumn{2}{|r|}{0.5} \\
\hline Max. horizontal linking distance $(\mathrm{m})$ & \\
\hline Max. vertical linking distance (m) & \multicolumn{2}{|r|}{5} \\
\hline Min. total swarm length (m) & \multicolumn{2}{|r|}{15} \\
\hline Min. total swarm height (m) & \multicolumn{2}{|r|}{2} \\
\hline
\end{tabular}


Post-processing of detected swarms: After detection, the physical properties of the swarms were corrected for beam geometry and threshold effects. Swarms that were too small to be corrected by the school correction algorithm were removed (Diner 2001). Corrected swarms were positively identified as krill using the variable $\Delta \mathrm{S}_{\mathrm{v} 120-38} \mathrm{~dB}$ window identification technique (CCAMLR 2009) and converted to abundance using the simplified stochastic distortedwave Born approximation target strength model (SDWBA) (McGehee et al. 1998, Demer \& Conti 2003, Conti \& Demer 2006, CCAMLR 2009). Minimum and maximum $\mathrm{S}_{\mathrm{v} 120-38}$ values for different size ranges of krill (identified from the net samples) were calculated using the SDWBA model, based on the distribution of $99 \%$ of the krill length frequencies estimated from a cumulative distribution function. Krill length frequency data were binned in $10 \mathrm{~mm}$ windows, rounded down to calculate the minimum limit, and rounded up to calculate the upper limit. The ranges used are detailed in Tarling et al. (2009), and are based on the CCAMLR recommended ranges (CCAMLR 2009). The simplified SDWBA was applied using fixed values for orientation $\mathrm{N}\left(11^{\circ}, 4^{\circ}\right)$ which represent the mean and standard deviation of the normal distribution of krill orientations relative to horizontal $\left(0^{\circ}\right)$, as defined by Demer \& Conti (2005). The material properties of krill were based on those calculated/inferred for the CCAMLR synoptic survey in the Scotia Sea region at the same time of year as the present study (CCAMLR 2009).

For spatial analysis, the cruise track was split into $1 \mathrm{~km}$ resets, and averages and counts were computed within each reset. Some of these segments of acoustic data had to be discarded due to sampling problems such as bad weather. A reset was deemed valid if the GPS fixes in the acoustic data had no gaps larger than $50 \mathrm{~m}$ after the elimination of the bad acoustic data. Time of day and position were taken from the starting point of each reset. The distance to the nearest point on the shoreline (of any landmass, e.g. either the islands or the Antarctic Peninsula) was computed using a great circle algorithm implemented in the $\mathrm{R}$ package 'sp' (Ihaka \& Gentleman 1996). Bottom depths were taken from the GEBCO_08 grid (version 20091120, www.gebco.net) closest to reset midpoints.

The data were split into night- and daytime observations, in order to check for diel effects. This split was done according to the local time of sunset and sunrise, with data accepted as 'daytime' if it was recorded between sunset and sunrise. Because the data was recorded during the Antarctic summer, it follows that 'daytime' data encompasses most of the data (Fig. 1).

Data were subsequently divided according to estimated distance to the shoreline into the following zones: 0 to 50,50 to 100,100 to 200 and $>200 \mathrm{~km}$. The choice of these zones match those of an accompanying study by Cresswell et al. (2009), where krill swarming and vertical migration behaviour is predicted to change over this cline as a function of the different levels of land-based predation and food availability. In referring to these zones, we use the terminology inshore/offshore to describe proximity to any landmass. Our definition only reflects distance away from shore and should not be confused with onshelf and off-shelf, which is a bathymetric categorisation. We detail the bathymetric ranges of the 4 zones in Fig. 2 as background information.

The distance between swarms was calculated from the midpoints of each krill swarm using the same algorithm as for calculation of distances to shoreline. Swarm acoustic biomass was expressed as the nautical area scattering coefficient (NASC, $\mathrm{m}^{2} \mathrm{n}$ mile ${ }^{-2}$ ) and the concentration of krill within swarms in terms of mean volume backscatter. All averaging and statistical analyses were undertaken in the linear domain $\left(\mathrm{s}_{\mathrm{v}} \mathrm{m}^{-1}\right)$. Conversion from acoustic to absolute numbers of krill was carried out using the predictions of the SDWBA model described at the beginning of this section ('Postprocessing of detected swarms').

Statistical differences in swarm properties and distribution between zones were tested for using a combination of a Mann-Whitney rank sum test and a Kruskal-Wallis 1-way ANOVA on rank test within the SIGMASTAT 2.03 software package.

\section{RESULTS}

A total of 4274 resets of $1 \mathrm{~km}$ were successfully completed across the entire survey area, distributed between the 4 zones as follows: 429 resets in the 0 to $50 \mathrm{~km}$ zone, 645 in the 50 to $100 \mathrm{~km}$ zone, 955 in the 100 to $200 \mathrm{~km}$ zone and 2245 in the $>200 \mathrm{~km}$ zone. A total of 11723 swarms were identified across all zones: 582 swarms in the 0 to 50 zone, 2239 in the 50 to $100 \mathrm{~km}$ zone, 3090 in the 100 to $200 \mathrm{~km}$ zone and 5812 in the $>200 \mathrm{~km}$ zone. Seventy percent of swarms were detected during the day and $30 \%$ at night. We examined how time of day affects the distribution of swarms and then controlled for these effects before further examination of the swarm's physical properties relative to the proximity of land.

\section{Day versus night swarming patterns}

Both the number and the acoustic biomass (NASC) of detected swarms per $\mathrm{km}$ were significantly lower during the night than the day across the whole survey grid 


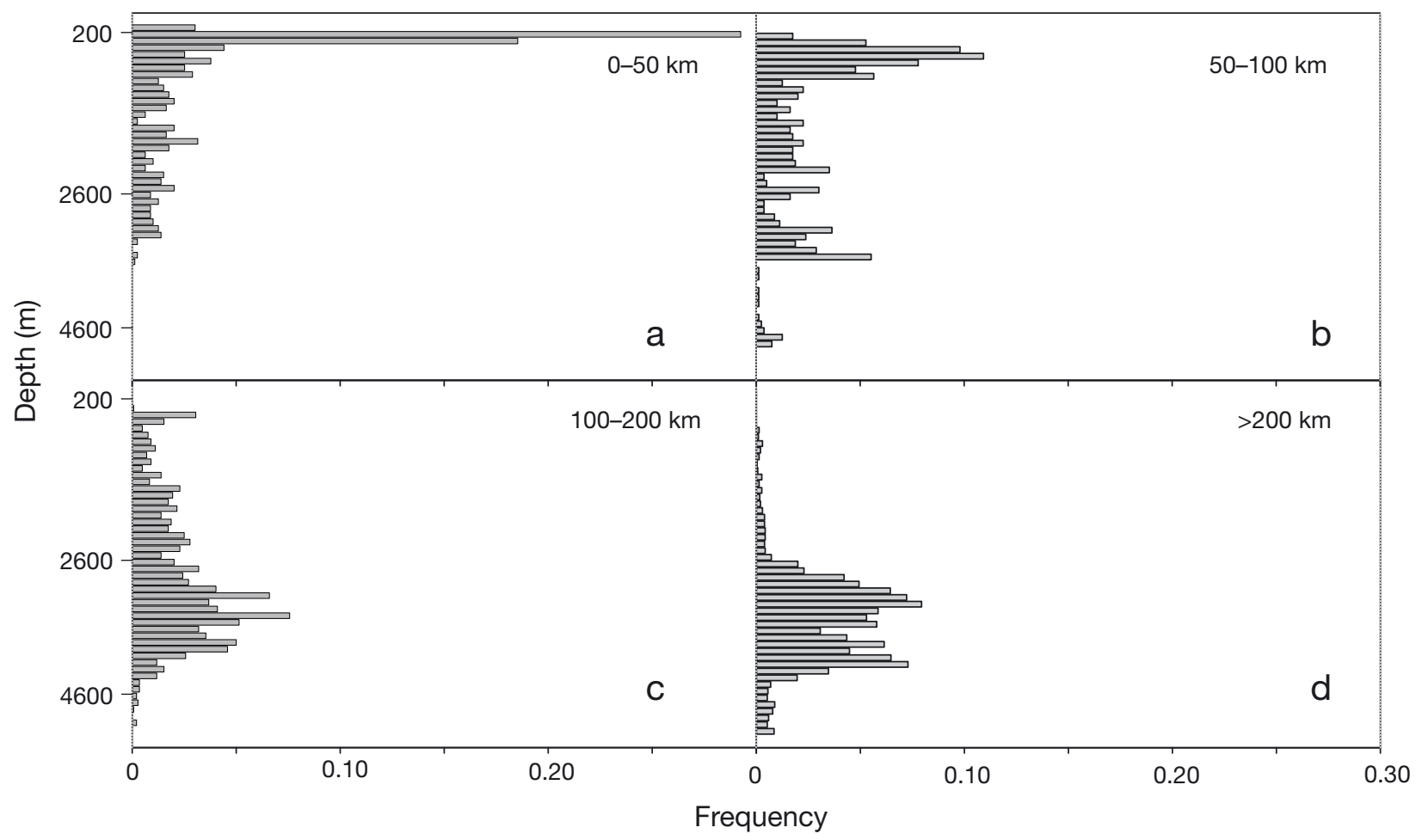

Fig. 2. Frequency distributions of depth of resets within the 4 land-proximity zones: (a) 0-50, (b) 50-100, (c) 100-200 and (d) $>200 \mathrm{~km}$

(Mann-Whitney rank sum test: NASC: p < 0.001; swarm numbers: $\mathrm{p}<0.001$ ). In fact, only about 1 in 3 of each $1 \mathrm{~km}$ reset surveyed during night-time contained swarms at all, whereas $>44 \%$ of daytime cells contained at least 1 swarm (Fig. 3).

Our approach was to separate the day and night data sets and focus mainly on the daytime data to minimise this potential bias in our analyses. We return to the issue of the depth distribution of swarms relative to time of day in a later section ('Vertical distribution of krill swarms').

\section{Physical properties of krill swarms}

Swarm area. Krill swarms were significantly larger in cross-sectional areas $\left(\mathrm{m}^{2}\right)$ in inshore zones $(<100 \mathrm{~km}$ from land) compared to zones further offshore (MannWhitney rank sum test, $\mathrm{p}<0.001$ ) (Fig. 4). The vast majority of swarms had an area of between 10 and $100 \mathrm{~m}^{2}$. However, the major difference between zones was observed in the greater proportion of swarms with areas above $1000 \mathrm{~m}^{2}$ in inshore areas. As a result, the median cross-sectional area was around $120 \mathrm{~m}^{2}$ in inshore regions and below $80 \mathrm{~m}^{2}$ further offshore (>100 km, Table 2).

Swarm volume backscattering strength $\left(\mathbf{S}_{\mathrm{v}}\right)$. The average $\mathrm{S}_{\mathrm{v}}$ of swarms was significantly greater in inshore compared to offshore zones (Kruskal-Wallis 1-way ANOVA on ranks: $H=190.91,3 \mathrm{df}, \mathrm{p}<0.001$ ) (Fig. 5). The $\mathrm{S}_{\mathrm{v}}$ of the majority of swarms was between $-65 \mathrm{~dB}$ and $-69 \mathrm{~dB}$. However, there was proportionally greater numbers of swarms with average $S_{v}$ values in excess of $-55 \mathrm{~dB}$ in inshore regions.

Inter-swarm distance. Typical inter-swarm distances differed significantly between zones (KruskalWallis 1-way ANOVA on ranks: $H=160.122,3 \mathrm{df}, \mathrm{p}<$ 0.001) (Fig. 6). Most notably, median inter-swarm distance in the 0 to $50 \mathrm{~km}$ zone $(194 \mathrm{~m})$ was around $60 \%$ larger than in all other zones $(\sim 100 \mathrm{~m})$. Fig. 6 shows that inter-swarm distances were log-normally distributed. The peak was comparatively broader in the 0 to $50 \mathrm{~km}$ zones as a result of the number of swarms with inter-swarms distances $>100 \mathrm{~m}$ being proportionally larger.

Swarm acoustic biomass (NASC). The NASC per swarm decreased significantly moving from inshore to offshore (Kruskal-Wallis 1-way ANOVA on ranks: $H=$ 276.08, 3 df, p < 0.001), with the median swarm acoustic biomass in the 0 to $50 \mathrm{~km}$ zone being more than twice that in the $>200 \mathrm{~km}$ zone $\left(50.7\right.$ and $20.6 \mathrm{~m}^{2}$ $\mathrm{n}$ mile $\mathrm{e}^{-2}$ respectively, Table 2 ). This is to be expected given that both the area and $\mathrm{S}_{\mathrm{v}}$ of swarms is greatest in inshore areas, and resulted in overall acoustic biomass peaking in the 0 to $50 \mathrm{~km}$ zone. Five percent of swarms had an acoustic biomass in excess of $10000 \mathrm{~m}^{2} \mathrm{n} \mathrm{mile}^{-2}$ 


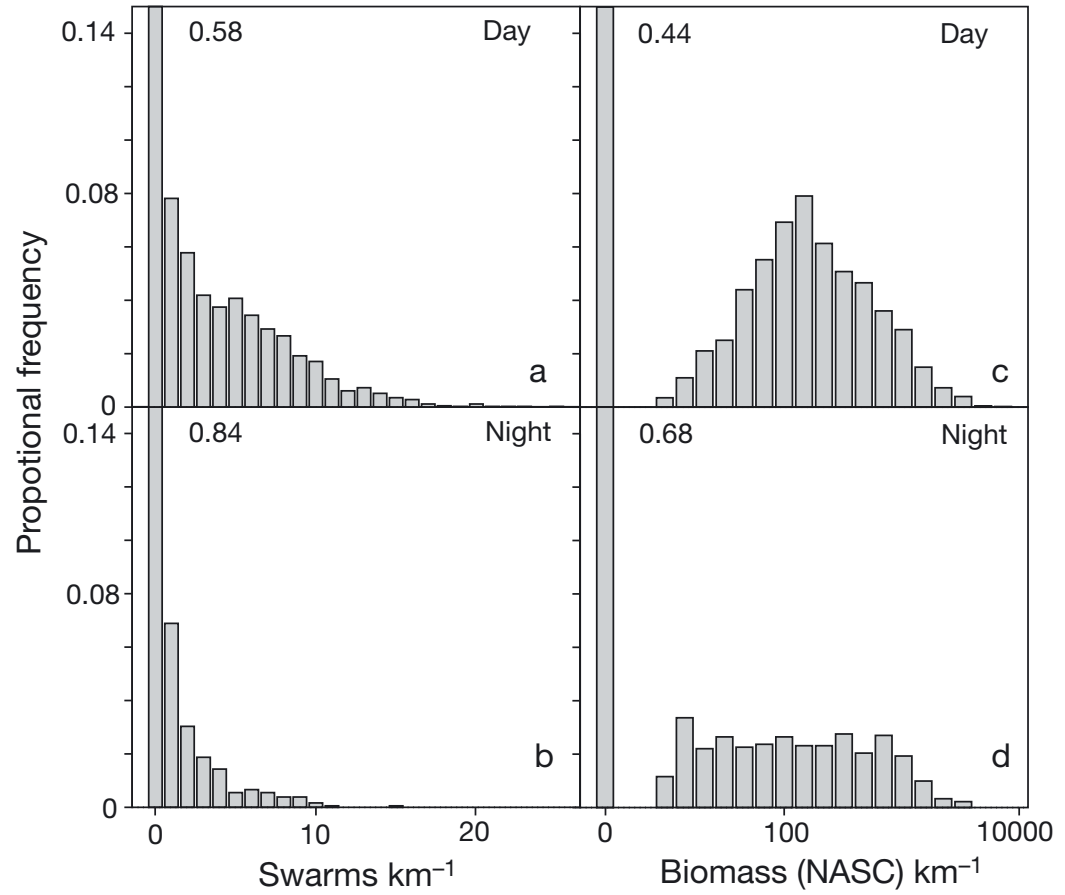

Fig. 3. Frequency distribution of swarms per km by (a) day and (b) night, and acoustic biomass (NASC) per km by (c) day and (d) night across the entire survey grid. Value on the top left of each graph represents the proportional frequency of 0 values (off-scale). NASC: nautical area scattering coefficient

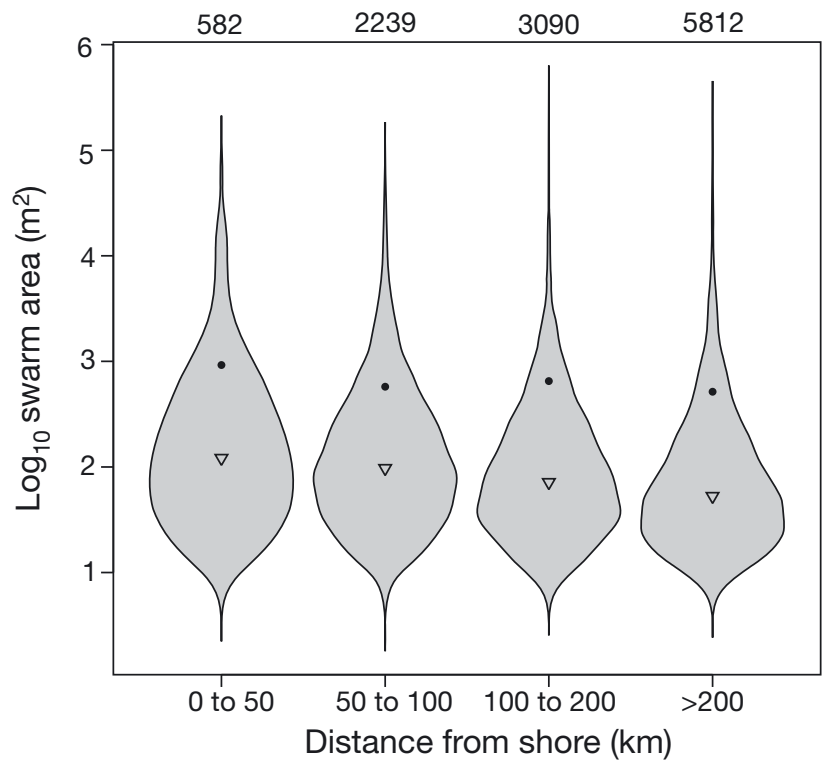

Fig. 4. Frequency distribution of log swarm area in different land-proximity zones. Inverted triangles: median, dots: mean, values. Frequencies in each respective zone were scaled such that the total area amounts to 1 . The total number of swarms within each zone is indicated at the top of each plot

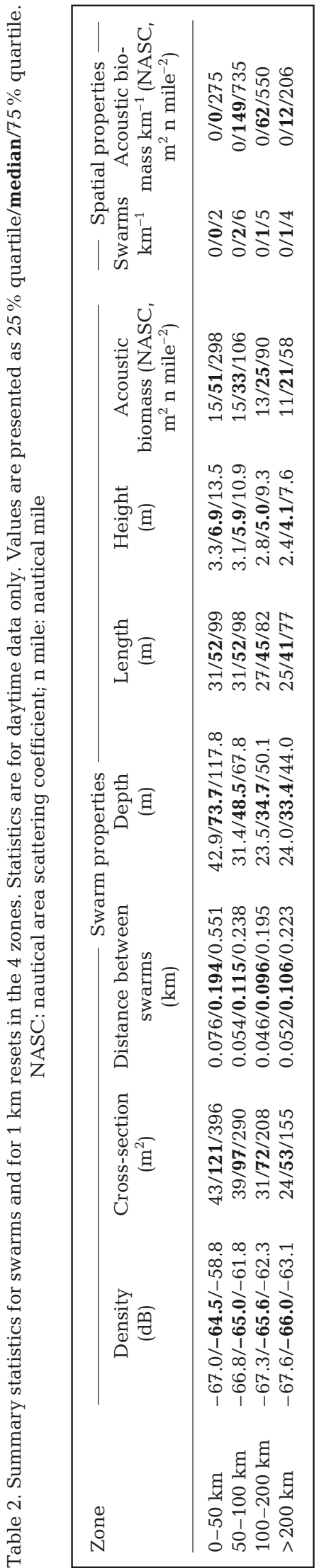


in the 0 to $50 \mathrm{~km}$ zone compared to $<1 \%$ in all other zones (Fig. 7). This is further seen in the relative contribution of individual swarms to total zone acoustic biomass. In the 0 to $50 \mathrm{~km}$ zone, swarms with an acoustic biomass in excess of $10000 \mathrm{~m}^{2} \mathrm{n} \mathrm{mile} \mathrm{e}^{-2}$ contributed

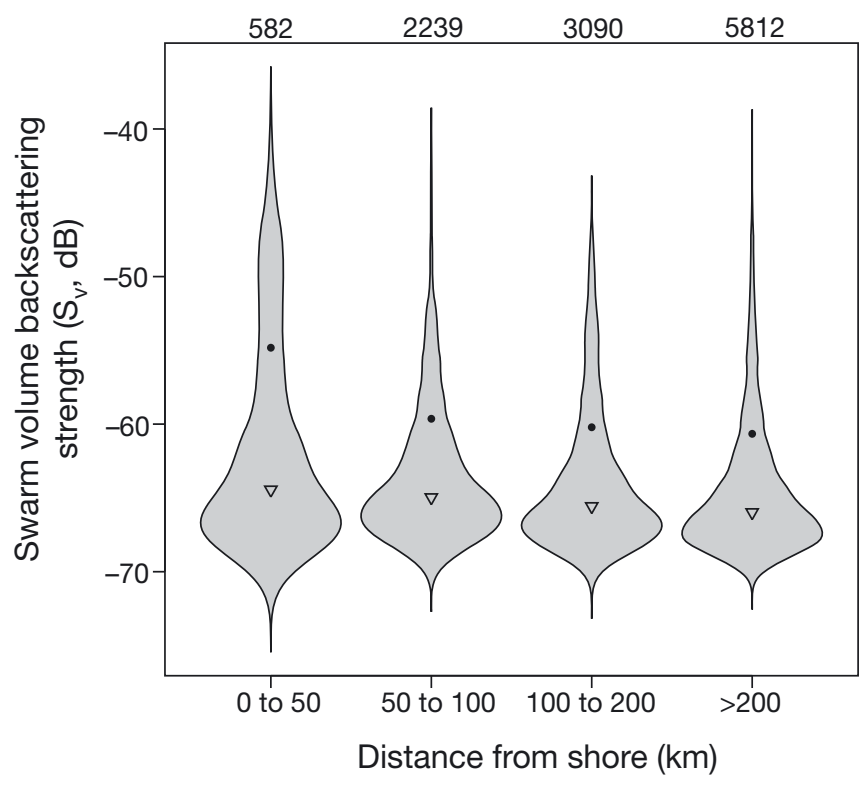

Fig. 5. Frequency distribution of volume backscattering strength $\left(\mathrm{S}_{\mathrm{v}}\right.$ re. $\left.1 \mathrm{~m}^{-1}, \mathrm{~dB}\right)$ in different land-proximity zones. Inverted triangles: median, dots: mean, values. Frequencies in each respective zone are scaled such that the total area amounts to 1 . The total number of swarms within each zone is indicated at the top of each plot

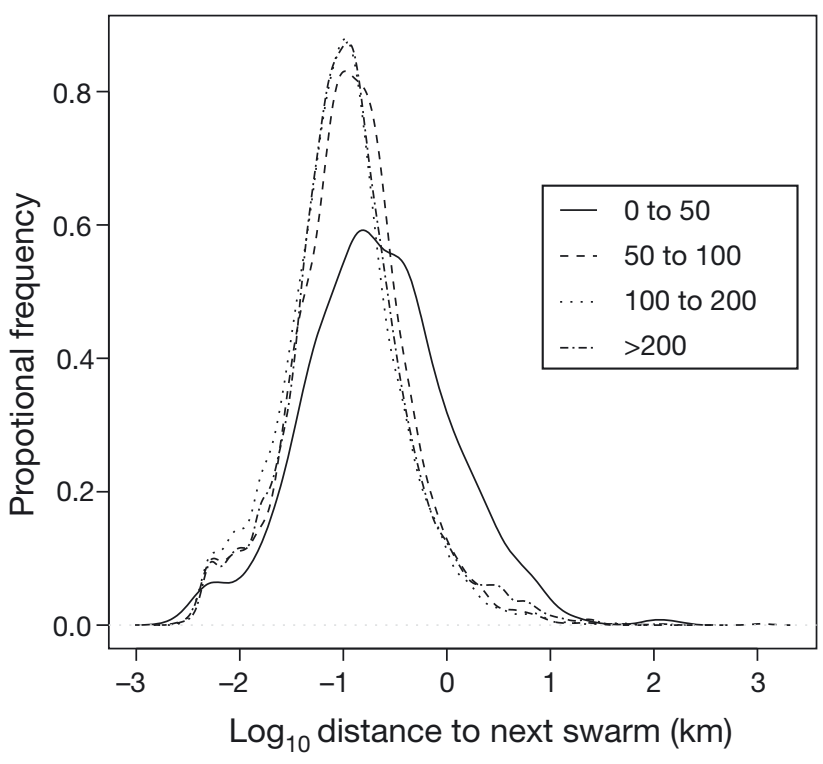

Fig. 6. Frequency distribution of inter-swarm distances in different land-proximity zones. Frequencies in each respective zone were scaled such that the total area beneath the curve amounts to 1
$46 \%$ of total zone acoustic biomass, while the contribution was 21,6 and $28 \%$ in the 50 to 100,100 to 200 and the $>200 \mathrm{~km}$ zones respectively.

\section{Horizontal distribution of krill swarms}

Swarm numbers per $\mathbf{k m}$. There were significantly more swarms per $\mathrm{km}$ in the 50 to $100 \mathrm{~km}$ zone than in any other zone (Kruskal-Wallis 1-way ANOVA on ranks: $H=106.43,3 \mathrm{df}, \mathrm{p}<0.001$ ), with a median of 2 swarms $\mathrm{km}^{-1}$ compared to $1 \mathrm{swarm} \mathrm{km} \mathrm{km}^{-1}$ in both the 100 to $200 \mathrm{~km}$ and the $>200 \mathrm{~km}$ zones, and 0 swarms $\mathrm{km}^{-1}$ in the 0 to $50 \mathrm{~km}$ zone. As shown in Fig. 8, however, the number of swarms encountered per $\mathrm{km}$ was quite variable. For instance, the maximum number of swarms was $18 \mathrm{~km}^{-1}$ in the 0 to $50 \mathrm{~km}$ zone and $26 \mathrm{~km}^{-1}$ in the 100 to $200 \mathrm{~km}$ zone. Furthermore, the proportion of $1 \mathrm{~km}$ sections containing no swarms at all ranged from $31 \%$ in the 50 to $100 \mathrm{~km}$ zone to $51 \%$ in the 0 to $50 \mathrm{~km}$ zone.

NASC per $\mathbf{k m}$. The median NASC per $\mathrm{km}$ in the 50 to $100 \mathrm{~km}$ zone was significantly higher than in any other zone (Kruskal-Wallis 1-way ANOVA on ranks: $H=113.96,3 \mathrm{df}, \mathrm{p}<0.001$ ) with a median value of $149 \mathrm{~m}^{2} \mathrm{n}$ mile $\mathrm{e}^{-2}$ compared to 62 and $12 \mathrm{~m}^{2} \mathrm{n} \mathrm{mile} \mathrm{e}^{-2}$ in the 100 to 200 and the $>200 \mathrm{~km}$ zones, respectively. Although the median value in the 0 to $50 \mathrm{~km}$ zone was 0 , meaning that over half the resets contained no krill swarms at all, this zone also had the highest NASC per $\mathrm{km}$, indicating that when krill was present, it occurred at very high levels of acoustic biomass (Fig. 9).

\section{Vertical distribution of krill swarms}

The majority of krill swarms were confined to the upper $50 \mathrm{~m}$ during the daytime in zones that were $>100 \mathrm{~km}$ from shore (Fig. 10a). Closer than $100 \mathrm{~km}$, there was a progressive spreading of swarms through the water column, such that a much greater fraction of swarms was found in the deeper parts of the water column. Hence, whereas $3 \%$ or less of swarms occurred deeper than $100 \mathrm{~m}$ in the offshore zones, the percentage increased to 8 and $34 \%$ in the 50 to 100 and the 0 to $50 \mathrm{~km}$ zones, respectively. Depths above $13 \mathrm{~m}$ were largely excluded as a result of surface-noise contamination.

Although we earlier (see 'Results - Day versus night swarming patterns') pointed to the potential bias in night-time data, it is instructive to examine this data set with respect to depth as a comparison to daytime distributions (Fig. 10b). One of the major differences between day and night was the apparent movement of the main centre of acoustic biomass to the upper part of 


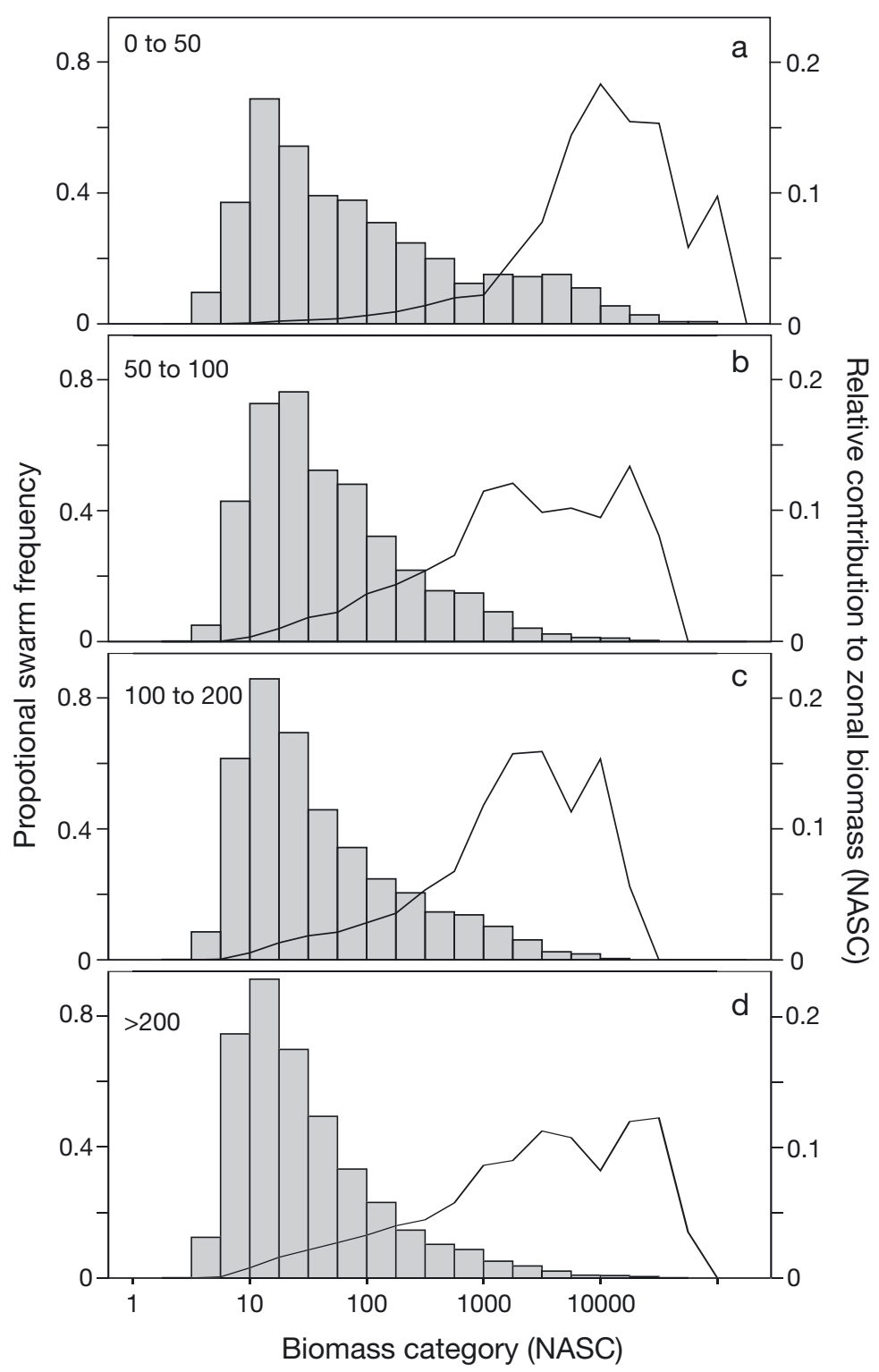

Fig. 7. Contribution of swarm frequency (bars) and swarm acoustic biomass (lines) to total zone acoustic biomass (NASC, $\mathrm{m}^{-2} \mathrm{n}$ mile ${ }^{-2}$ ) in the 4 land-proximity zones: (a) 0-50, (b) 50-100, (c) 100-200 and (d) $>200 \mathrm{~km}$. NASC: nautical area scattering coefficient; $\mathrm{n}$ mile: nautical mile

with one part of the population located in the upper water column and the other deeper than $100 \mathrm{~m}$.

\section{Swarm packing concentrations and acoustic biomass}

Table 3 gives swarm packing concentrations (ind. $\mathrm{m}^{-3}$ ), and swarm biomass density $\left(\mathrm{g} \mathrm{m}^{-3}, \mathrm{~g} \mathrm{~m}^{-1}\right)$ values typically seen across the zones surveyed in the present study. The inshore zone ( 0 to $50 \mathrm{~km}$ ) had the highest average swarm density of 95 ind. $\mathrm{m}^{-3}$, which equated to $41 \mathrm{~g} \mathrm{~m}^{-3}$ (Table 3 ). Average swarm densities in the outer zones (>50 km from shore) were between 24 and 31 ind. $\mathrm{m}^{-3}$ (14 to $17 \mathrm{~g} \mathrm{~m}^{-3}$ ). Swarm biomass density ranged between 0.6 and $1823 \mathrm{~g} \mathrm{~m}^{-3}$ across all zones, although values $>500 \mathrm{~g} \mathrm{~m}^{-3}$ occurred in $<0.4 \%$ of swarms. Swarm sum biomass ranged between 4.6 and $4528821 \mathrm{~g} \mathrm{~m}^{-1}$.

\section{DISCUSSION}

There were significant differences in the distribution and characteristics of swarms across the Scotia Sea in relation to the proximity of land during summer 2003. In particular, we found that large proportions of krill acoustic biomass inshore (0 to $50 \mathrm{~km}$ from land) were packed into a small number of large, acoustically dense swarms. Inshore swarms were also likely to be deeper than those further offshore. Both characteristics suggest that the krill were responding to predatory threat, although other factors such as food availability and the physical properties of the water column may also contribute to this pattern.

\section{Horizontal distribution of swarms}

the water column ( 0 to $50 \mathrm{~m}$ ) in the inshore zones ( $<100 \mathrm{~km}$ from shore) at night. The most likely explanation is the diel vertical migration (DVM) of the population to the surface during night-time (normal DVM). However, contrasting with that pattern is an apparent reverse DVM in the zones further than $100 \mathrm{~km}$ from shore, with the population spreading to deeper parts of the water column during the night: $16 \%$ of swarms were found below $100 \mathrm{~m}$ during the night-time as opposed to $<3 \%$ during the day. Also notable was bimodality in certain night-time depth distributions,
We found that the majority of krill acoustic biomass resided in a relatively small number of swarms, with $>50 \%$ of acoustic biomass occurring in $<1 \%$ of swarms. Large swarms were particularly common in the 0 to $50 \mathrm{~km}$ zone. The acoustic density of inshore swarms was also significantly greater than that of offshore swarms. A further interesting aspect of the 0 to $50 \mathrm{~km}$ zone was that the median acoustic biomass within $1 \mathrm{~km}$ resets was 0 , yet the zone also had the highest average acoustic biomass per km. By compari- 


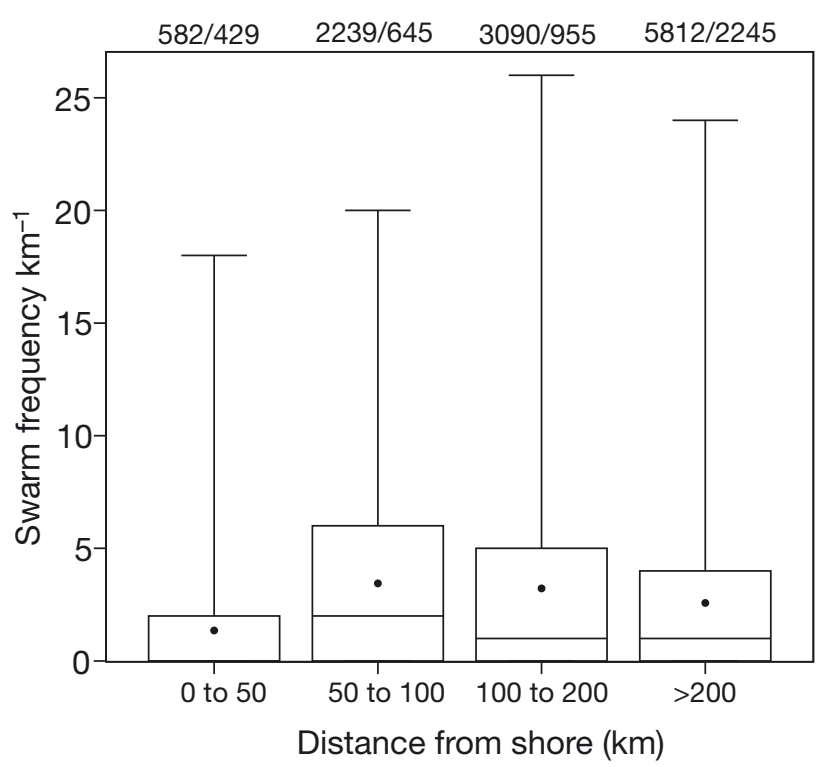

Fig. 8. Distribution of swarms per $\mathrm{km}$ in different landproximity zones. Boxes extend from lower to upper quartile, with median shown by a horizontal bar. Whiskers extend to maximum values. Dot represents average number of swarms per $\mathrm{km}$ observed in each zone. Numbers at the top of each plot indicate total number of swarms and number of $1 \mathrm{~km}$ resets respectively

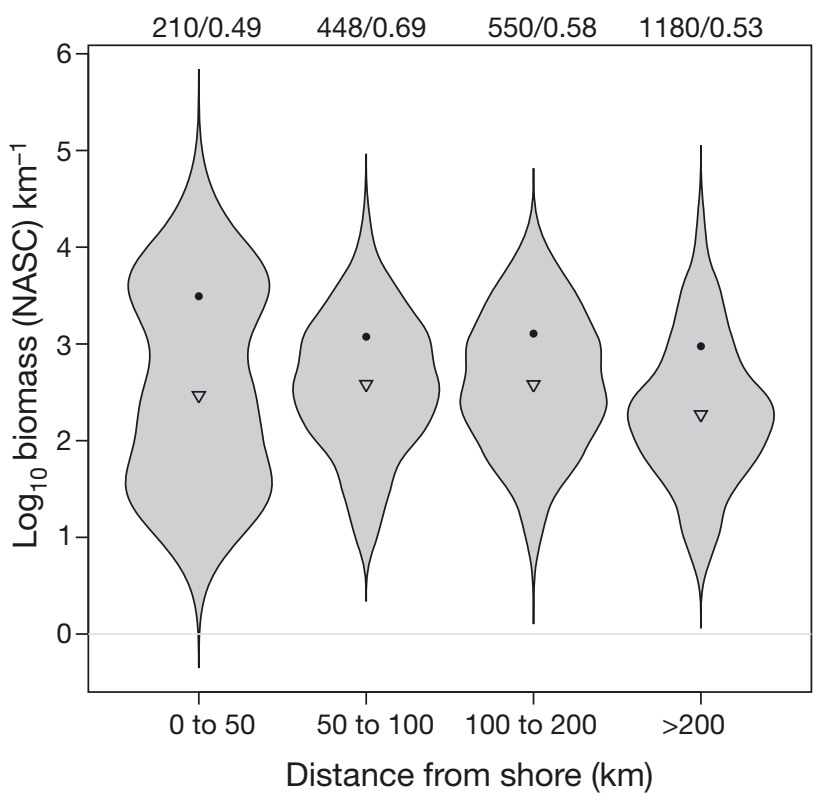

Fig. 9. Frequency distribution of log acoustic biomass per $\mathrm{km}$ in different land-proximity zones. Data is restricted to those resets that contain krill. Inverted triangles: median, dots: mean, values. Frequencies in each respective zone were scaled such that the total area amounts to 1 . Numbers at the top of each plot indicates respectively the total number of resets and the proportion of resets containing krill in each zone son, zones further offshore had a much closer match between the median and the mean acoustic biomass per $\mathrm{km}$. This indicates that krill swarms in the inshore zone were not only larger and acoustically denser, but also more patchily distributed than further offshore.

The uneven distribution of biomass between swarms has been previously reported in a number of acoustic studies (Miller \& Hampton 1989b, Hewitt \& Demer 1993, Murray et al. 1995, Ross et al. 1996, Lascara et al. 1999, Pauly et al. 2000, Lawson et al. 2008b). Nevertheless, the present study is the first to report that the degree to which this distribution becomes uneven increases with proximity to land. Predation from land-based airbreathing predators is probably the largest source of mortality during the summertime in the Scotia Sea (Boyd 2002). Increasing swarm density provides better surveillance capacity and the denser or more integrated the school, the faster the propagation of an escape response through aggregation (O'Brien 1987). Zhou \& Dorland (2004) found that krill aggregated more densely in the presence of predators. Cox et al. (2009) showed that the topography of the swarm edge (the roughness) altered depending on the proximity of predators. Predators are cognitively constrained in being able to track individuals that are visually indistinguishable (Krakauer 1995) and capture rates decrease as group size increases (Landeau \& Terborgh 1986).

Studies into interactions between krill and its predators have stressed the importance of especially large patches to foraging behaviour (Heinemann et al. 1989, Veit \& Hunt 1991, Veit et al. 1993). Veit et al. (1993) reported that birds and seals bypassed smaller aggregations of krill in anticipation of finding a larger one later on. Although large swarms may be visible from greater distances than small swarms, this may be counteracted by the resultant larger-scale patchiness, which makes the probability of interception by a randomly searching predator less likely. In general, it is assumed that predation risk increases with the local density of aggregations, since predators are attracted by groups (Hofmann et al. 2004). However, in inshore regions, the main predation threat is from penguins and seals, which only have a small search radius and difficulties in detecting distant groups of prey or feeding aggregations of other predators (Hunt et al. 1992). Forming into large, dense swarms may therefore be the best strategy for krill to avoid detection when inshore.

We found that the 50 to $100 \mathrm{~km}$ zone contained the most swarms per $\mathrm{km}$, whereas the 0 to $50 \mathrm{~km}$ zone had the highest acoustic biomass (NASC) per km. Trathan et al. (2003) found that bathymetry was a consistent predictor of krill abundance, with abundance being greatest nearest the shelf break, whereas Lawson et al. (2008b) found the highest biomass in regions close to land during winter and autumn. In East Antarctica 


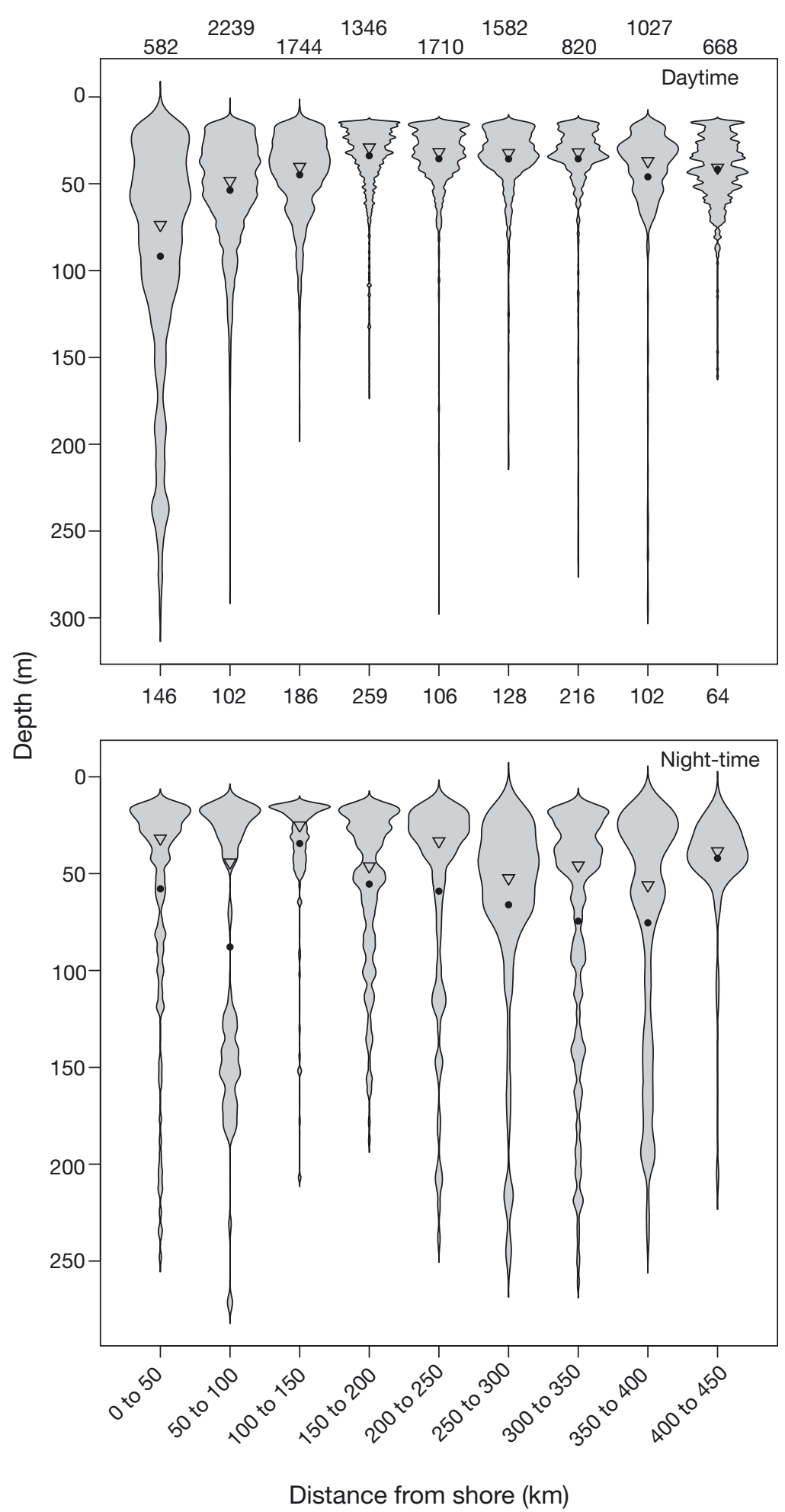

Fig. 10. (a) Daytime and (b) night-time vertical distribution of swarms with respect to distance from shore. Zones were sub-divided into $50 \mathrm{~km}$ intervals to a maximum $450 \mathrm{~km}$ from the shore. Frequencies in each respective $50 \mathrm{~km}$ interval were scaled such that the total area amounted to 1 . Inverted triangles: median, dots: mean, values. The total number of swarms within each zone is indicated at the top of each plot. Note that some areas within the 0 to $50 \mathrm{~km}$ zone were shallower than $300 \mathrm{~m}$
(80 to $150^{\circ} \mathrm{E}$ ), Pauly et al. (2000) found that krill aggregations were most frequently encountered in the shelf break region, where the summer ice edge, $1000 \mathrm{~m}$ isobaths and the Antarctic slope front coincided.

Continental shelf and shelf-edge environments in the Southern Ocean are frequently associated with semi-permanent phytoplankton blooms (Korb \& Whitehouse 2004, Pollard et al. 2007), which are ideal feeding environments for krill.

Meanwhile, predator species show a decrease in density with increasing distance from colonies (Hunt et al. 1992). The shelf-edge zone may therefore provide an ideal compromise between food availability and predator avoidance. Nevertheless, shelf-edge environments also contain strong current flows (Meredith et al. 2003a,b) and krill may find it difficult to retain position within such environments (Cresswell et al. 2007). Atkinson et al. (2008) compared krill biomass across continental shelf and oceanic regions in the Atlantic sector of the Southern Ocean and found that, although krill density was 1.65 times higher over shelves, they contained only $13 \%$ of the total krill stock in the sector, with the remainder occurring over deep oceanic areas. They concluded that while growth rates are higher in productive shelf regions, the ocean provides a refuge from shelf-based predators (Atkinson et al. 2008).

\section{Vertical distribution of swarms}

In all zones, the majority of krill swarms were found in the upper $100 \mathrm{~m}$. Lascara et al. (1999) similarly found that the vertical distribution of oceanic krill in summer was skewed towards the surface, with only $25 \%$ of biomass deeper than $50 \mathrm{~m}$ and hardly any biomass below $100 \mathrm{~m}$. Nevertheless, we found that the vertical distribution pattern changed closer to shore, with a spreading of the population through the water column such that almost $34 \%$ of the population was found deeper than $100 \mathrm{~m}$ in the 0 to $50 \mathrm{~km}$ zone. Residing deeper in the 
Table 3. Equivalent average swarm densities between acoustic and absolute units using the simplified stochastic distorted-wave Born approximation (SDWBA) target strength model (McGehee et al. 1998, Demer \& Conti 2003, Conti \& Demer 2006, CCAMLR 2009). Target strength values were calculated on a region-specific basis according to the length-frequency distributions of the krill population. Three major regions were distinguished on this basis: southwest Scotia Sea (SW), northeast Scotia Sea (NE) and South Georgia (SG). Target strengths $(\mathrm{dB})$ calculated with the SDWBA model were applied to determine swarm packing concentrations (ind. $\mathrm{m}^{-3}$ ) as follows: SW: $-74.6607, \mathrm{NE}$ : -74.4974 and SG: -74.448 . Swarm biomass density $\left(\mathrm{g} \mathrm{m}^{-3}\right)$ was calculated by multiplication of ind $\mathrm{m}^{-3}$ by the following factors: SW: $0.27480, \mathrm{NE}$ : 0.69565 and SG: 0.800814 . Swarm biomass density was multiplied by swarm cross-sectional area to give swarm sum biomass $\left(\mathrm{g} \mathrm{m}^{-1}\right)$. Only daytime data were used in these calculations

\begin{tabular}{|lcccr|}
\hline Zone & $\begin{array}{c}\text { Volume } \\
\text { backscattering } \\
\text { strength } \\
\left(\mathrm{S}_{\mathrm{v}} \text { re. } 1 \mathrm{~m}^{-1}, \mathrm{~dB}\right)\end{array}$ & $\begin{array}{c}\text { Packing } \\
\text { concentration } \\
\left(\text { ind. } \mathrm{m}^{-3}\right)\end{array}$ & $\begin{array}{c}\text { Biomass } \\
\text { density } \\
\left(\mathrm{g} \mathrm{m}^{-3}\right)\end{array}$ & $\begin{array}{c}\text { Sum } \\
\text { biomass } \\
\left(\mathrm{g} \mathrm{m}^{-1}\right)\end{array}$ \\
\hline $0-50 \mathrm{~km}$ & -54.82 & 95.03 & 41.11 & 40094.49 \\
$50-100 \mathrm{~km}$ & -59.64 & 31.17 & 15.38 & 8143.30 \\
$100-200 \mathrm{~km}$ & -60.21 & 27.26 & 14.03 & 12331.80 \\
$>200 \mathrm{~km}$ & -60.66 & 24.22 & 16.85 & 10374.69 \\
\hline
\end{tabular}

water column is a classic strategy to reduce the predation threat from visually foraging predators and is also likely to be a particularly effective strategy against airbreathing diving predators. Eighty percent of Antarctic fur seal and macaroni penguin dives are shallower than 40 to $60 \mathrm{~m}$ (Croxall et al. 1985, 1988) and these predators are also less likely to travel more than $100 \mathrm{~km}$ away from their colony. Hunt et al. (1992) found that $75 \%$ of Antarctic fur seals and macaroni penguins at sea occurred 18 to $56 \mathrm{~km}$ away from land. The threat of surface-based predation may explain why krill in inshore regions were more likely to reside deep in the water column. This threat is lower in offshore regions, which may allow the krill here to occupy shallow depths throughout the diel period. While we interpret the vertical behaviour of krill to be dependent on the predators, the reverse is also likely to be true. For instance, Staniland \& Boyd (2003) found that fur seals perform more deep daytime dives when on-shelf compared to off-shelf.

By night-time, almost all krill swarms in the inshore region were found in the upper $50 \mathrm{~m}$, which is consistent with a classic DVM pattern. If krill occupy deep, unproductive layers in the daytime, their high energetic requirement necessitates a migration into the productive surface layers during the night-time to feed. DVM is observed in many zooplankton species and is sometimes thought of as a relatively fixed behaviour controlled by the light cycle (Ringelberg 1995). However, Cresswell et al. (2009) predicted distinct selective advantages to those krill capable of altering depth in relation to predation risk over short time scales. The present study gives evidence of krill reacting to predator disturbance through spreading through the water column. Zamon et al. (1996) showed that penguins will target the layer where the relative volumetric contribution of moderate to high krill density levels is greatest. Escape from this threat would be achieved through moving either up or down the water column, which may drive the observed vertical spreading of krill.

Further evidence of the relative flexibility of krill migration is seen offshore, where swarms adopt a deeper position in the water during night-time than during the day. Such reverse DVM has been previously reported in Antarctic krill by Godlewska (1996), but it is unclear as to the exact cause and/or benefit of this behaviour in the present context. One potential explanation is that feeding activity increases during night-time and swarms sink when constituent individuals become satiated (sensu Tarling \& Johnson 2006). Alternatively, such swarms may be comprised of individuals that are moulting in a synchronised manner (Buchholz 1991), and so have a reduced swimming capacity (Thomasson et al. 2003).

Nevertheless, we found that both swarm numbers and acoustic biomass were apparently lost from the water column during night-time. This was probably because either some swarms had dispersed and fell below our threshold detection level or had migrated above the depths visible to our echosounder. It is therefore possible that the numbers of swarms in the deeper layers remained approximately the same both day and night, but that the deep night-time swarms became relatively more important as a result of the loss of swarms above the echosounder.

\section{Swarm packing concentrations and acoustic biomass}

We mainly expressed the acoustic density and biomass of krill swarms in terms of the acoustic units $\mathrm{S}_{\mathrm{v}}$ $(\mathrm{dB})$ and NASC $\left(\mathrm{m}^{-2} \mathrm{n} \mathrm{mile}^{-2}\right)$ respectively. Converting from acoustic units to absolute krill numbers is very sensitive to target strength models, which are under continual development (CCAMLR 2009). Providing results in terms of acoustic units allows conversions to be made as and when further target strength models are published. In our own conversion (Table 3), we used the simplified SDWBA model (McGehee et al. 1998, Demer \& Conti 2003, Conti \& Demer 2006). 
We found that the density of biomass within swarms ranged between 0.6 and $1823 \mathrm{~g} \mathrm{~m}^{-3}$ across all zones, with the highest average levels $\left(41 \mathrm{~g} \mathrm{~m}^{-3}\right)$ being found inshore. These values are broadly in line with previous acoustic studies within this sector of the Southern Ocean. Ricketts et al. (1992) found average densities of $33 \mathrm{~g} \mathrm{~m}^{-3}$ and Kalinowski \& Witek (1985), $72 \mathrm{~g} \mathrm{~m}^{-3}$. Lascara et al. (1999) reported densities of between 150 and $500 \mathrm{~g} \mathrm{~m}^{-3}$. It is to be noted that such acoustically estimated densities are well below estimated densities of visually observed krill schools, where values of up to $15000 \mathrm{~g} \mathrm{~m}^{-3}$ have been reported (Hamner \& Hamner 2000).

Harmonising swarm biomass estimates between methods remains a major challenge in krill science.

\section{Implications for fisheries management}

We found that swarms in offshore regions were more frequently encountered but contained relatively low acoustic biomass and packing concentrations of krill. Inshore, swarms were more sparsely distributed but contained greater amounts of krill acoustic biomass. From the perspective of a fishing vessel, although swarms would be commonly found offshore, the yields from fishing such swarms would be relatively low. Inshore, a much greater effort would be required in searching for swarms but, once located, the yields per swarm will be relatively high. These findings agree with those of Hill et al. (2009), who found that areas suitable for krill exploitation were more common in shallower water (i.e. closer to shore) than in deeper water (i.e. further offshore). The study by Hill et al. (2009) was based on a re-analysis of acoustic data from a series of simultaneous cruises carried out in the Scotia Sea in 2000 (Hewitt et al. 2004). Hill et al. (2009) also examined fishery data for the past $10 \mathrm{yr}$ and found that the majority of reported catches were taken in inshore regions. This may result from a combination of the abundance of on-shelf krill and the ease of access from mooring locations that provide shelter and stable anchorages for processing.

The management of the krill fishery in the Southern Ocean by CCAMLR takes an ecosystem approach, aiming to balance the requirements of the target species, the wider ecosystem and the fishery itself. Further development of this management strategy may include spatial restrictions on harvesting, particularly a limit on the level of fishing in inshore areas where krill predators are most affected. Whether or not such a limitation would be detrimental to the fishery will depend on a number of factors, including the exact size and density thresholds for profitable fishing of swarms and the effect of small-scale swarm distribution on searching times. We recommend that focusing on patterns of swarm structure and distribution provides a powerful means by which to inform these management decisions.

\section{CONCLUSIONS}

Quantifying the availability of pelagic prey to diving predators is a complicated problem and acoustic characterisation of the prey field is one important step towards a fuller understanding of predator-prey interactions in marine environments (Zamon et al. 1996). Overall, we found that krill were patchier and less available to predators inshore $(<50 \mathrm{~km}$ from land). They reached peak acoustic biomass in the 0 to $50 \mathrm{~km}$ zone, though the highest number of swarms per $\mathrm{km}$ was found in the 50 to $100 \mathrm{~km}$ zone. Veit et al. (1993) concluded that the distribution of krill predators was disproportionately influenced by a few large swarms of krill. It is these large swarms that are also of most interest to krill trawlers (Mangel 1988). Both predators and trawlers are therefore likely to focus on the same regions and this potential conflict must be managed effectively in future krill-fishery policy.

Acknowledgements. We thank the crew and scientists aboard the RRS 'James Clark Ross' during the cruise JR82 for their assistance in collecting material. We also thank D. Bone for assembling and maintaining the net gear and N. Cunningham for organising and retrieving data. This work was carried out as part of the DISCOVERY2010 and ECOSYSTEMS programmes at the British Antarctic Survey. The contribution of T.A.K. was funded by the NARE programme. Comments from the anonymous referees greatly improved this work.

\section{LITERATURE CITED}

Aksnes DL, Giske J (1993) A theoretical model of aquatic visual feeding. Ecol Model 67:233-250

Antezana T, Ray K (1983) Aggregation of Euphausia superba as an adaptive group strategy to the Antarctic ecosystem. Ber Polarforsch 4:199-215

Atkinson A, Siegel V, Pakhomov EA, Rothery P and others (2008) Oceanic circumpolar habitats of Antarctic krill. Mar Ecol Prog Ser 362:1-23

Boyd IL (2002) Estimating food consumption of marine predators: Antarctic fur seals and macaroni penguins. J Appl Ecol 39:103-119

Buchholz F (1991) Moult cycle and growth of Antarctic krill Euphausia superba in the laboratory. Mar Ecol Prog Ser 69:217-229

CCAMLR (Commission for the Conservation of Antarctic Marine Living Resources) (2009) Report of the fourth meeting of the subgroup on acoustic survey and analysis methods (Ancona, Italy, 25 to 28 May 2009). SC-CAMLRXXVIII/8

Coetzee J (2000) Use of a shoal analysis and patch estimation system (SHAPES) to characterize sardine schools. Aquat Living Resour 13:1-10 
Conti SG, Demer DA (2006) Improved parameterization of the SDWBA for estimating krill target strength. ICES J Mar Sci 63:928-935

> Cox MJ, Demer DA, Warren JD, Cutter GR, Brierley AS (2009) Multibeam echosounder observations reveal interactions between Antarctic krill and air-breathing predators. Mar Ecol Prog Ser 378:199-209

Cresswell KA, Tarling GA, Burrows MT (2007) Behaviour affects local-scale distributions of Antarctic krill around South Georgia. Mar Ecol Prog Ser 343:193-206

Cresswell K, Tarling G, Thorpe S, Burrows M, Wiedemann J, Mangel M (2009) Diel vertical migration of Antarctic krill (Euphausia superba) is flexible during advection across the Scotia Sea. J Plankton Res 31:1265-1281

Croll DA, Tershy BR, Hewitt RP, Demer DA and others (1998) An integrated approach to the foraging ecology of marine birds and mammals. Deep-Sea Res II 45:1353-1371

Croxall JP, Everson I, Kooyman GL, Ricketts C, Davis RW (1985) Fur-seal diving behavior in relation to vertical distribution of krill. J Anim Ecol 54:1-8

> Croxall JP, Davis RW, O'Connell MJ (1988) Diving patterns in relation to diet of Gentoo and Macaroni penguins at South Georgia. Condor 90:157-167

> Demer DA, Conti SG (2003) Validation of the stochastic distorted-wave Born approximation model with broad bandwidth total target strength measurements of Antarctic krill. ICES J Mar Sci 60:625-635

> Demer DA, Conti SG (2005) New target-strength model indicates more krill in the Southern Ocean. ICES J Mar Sci 62:25-32

Diner N (2001) Correction on school geometry and density: approach based on acoustic image simulation. Aquat Living Resour 14:211-222

Foote KG, Knudsen FR, Vestnes G, MacLennan DN, Simmonds EJ (1987) Calibration of acoustic instruments for fish density estimation: a practical guide. ICES Coop Res Rep 144

Godlewska M (1996) Vertical migrations of krill (Euphausia superba Dana). Pol Arch Hydrobiol 14:9-63

Hamner WM, Hamner PP (2000) Behavior of Antarctic krill (Euphausia superba): schooling, foraging, and antipredatory behavior. Can J Fish Aquat Sci 57:192-202

Heinemann D, Hunt G, Everson I (1989) Relationships between the distributions of marine avian predators and their prey, Euphausia superba, in Bransfield Strait and southern Drake Passage, Antarctica. Mar Ecol Prog Ser $58: 3-16$

> Hewitt RP, Demer DA (1993) Dispersion and abundance of Antarctic krill in the vicinity of Elephant Island in the 1992 austral summer. Mar Ecol Prog Ser 99:29-39

Hewitt RP, Watkins J, Naganobu M, Sushin V and others (2004) Biomass of Antarctic krill in the Scotia Sea in January/February 2000 and its use in revising an estimate of precautionary yield. Deep-Sea Res II 51:1215-1236

> Hill S, Trathan P, Agnew D (2009) The risk to fishery performance associated with spatially resolved management of Antarctic krill (Euphausia superba) harvesting. ICES J Mar Sci 66:2148-2154

Hofmann EE, Haskell AGE, Klinck JM, Lascara CM (2004) Lagrangian modelling studies of Antarctic krill (Euphausia superba) swarm formation. ICES J Mar Sci 61:617-631

> Hunt GL Jr, Heinemann D, Everson I (1992) Distributions and predator-prey interactions of macaroni penguins, Antarctic fur seals, and Antarctic krill near Bird Island, South Georgia. Mar Ecol Prog Ser 86:15-30

> Ihaka R, Gentleman R (1996) R: a language for data analysis and graphics. J Comput Graph Statist 5:299-314
Kalinowski J, Witek Z (1985) Scheme for classifying Antarctic krill. BIOMASS Handb Ser 27:1-12

Korb RE, Whitehouse M (2004) Contrasting primary production regimes around South Georgia, Southern Ocean: large blooms versus high nutrient, low chlorophyll waters. Deep-Sea Res I 51:721-738

- Krakauer DC (1995) Groups confuse predators by exploiting perceptual bottlenecks: a connectionist model of the confusion effect. Behav Ecol Sociobiol 36:421-429

Landeau L, Terborgh J (1986) Oddity and the confusion effect in predation. Anim Behav 34:1372-1380

Lascara CM, Hofmann EE, Ross RM, Quetin LB (1999) Seasonal variability in the distribution of Antarctic krill, Euphausia superba, west of the Antarctic Peninsula. Deep-Sea Res I 46:951-984

> Lawson GL, Wiebe PH, Stanton TK, Ashjian CJ (2008a) Euphausiid distribution along the Western Antarctic Peninsula-Part A: development of robust multifrequency acoustic techniques to identify euphausiid aggregations and quantify euphausiid size, abundance and biomass. Deep-Sea Res II 55:412-431

Lawson GL, Wiebe PH, Ashjian CJ, Stanton TK (2008b) Euphausiid distribution along the Western Antarctic Peninsula - Part B: distribution of euphausiid aggregations and biomass, and associations with environmental features. Deep-Sea Res II 55:432-454

Mangel M (1988) Analysis and modelling of the Soviet Southern Ocean krill fleet. In: Selected scientific papers, 1988 (SC-CAMLRSSSP/5), Part I. CCAMLR, Hobart, Australia, p $127-236$

McGehee DE, O'Driscoll RL, Traykovski LVM (1998) Effects of orientation on acoustic scattering from Antarctic krill at 120 kHz. Deep-Sea Res II 45:1273-1294

Meredith MP, Watkins JL, Murphy EJ, Cunningham NJ and others (2003a) An anticyclonic circulation above the Northwest Georgia Rise, Southern Ocean. Geophys Res Lett 30:2061 doi:10.1029/2003GL018039

Meredith MP, Watkins JL, Murphy EJ, Ward P and others (2003b) Southern ACC front to the northeast of South Georgia: pathways, characteristics, and fluxes. J Geophys Res Oceans 108:3162-3178

Miller DGM, Hampton I (1989a) Biology and ecology of the Antarctic krill, Vol 9. SCAR: Scientific Committee for Antarctic Research, Cambridge, UK

> Miller DGM, Hampton I (1989b) Krill aggregation characteristics: spatial distribution patterns from hydroacoustic observations. Polar Biol 10:125-134

Miller DGM, Barange M, Klindt H, Murray AWA, Hampton I, Siegel V (1993) Antarctic krill aggregation characteristics from acoustic observations in the Southwest Atlantic Ocean. Mar Biol 117:171-183

> Mori Y, Boyd IL (2004) The behavioral basis for nonlinear functional responses and optimal foraging in Antarctic fur seals. Ecology 85:398-410

- Murphy EJ, Watkins JL, Trathan PN, Reid K and others (2007) Spatial and temporal operation of the Scotia Sea ecosystem: a review of large-scale links in a krill centred food web. Phil Trans R Soc B 362:113-148

Murray AW, Watkins JL, Bone DG (1995) A biological acoustic survey in the marginal ice-edge zone of the Bellingshausen Sea. Deep-Sea Res II 42:1159-1175

> Nicol S (1984) Population structure of daytime surface swarms of the euphausiid Meganyctiphanes norvegica in the Bay of Fundy. Mar Ecol Prog Ser 18:241-251

> Nicol S (2006) Krill, currents and sea-ice: Euphausia superba and its changing environment. Bioscience 56:111-120

O'Brien DP (1987) Description of escape responses of krill 
(Crustacea, Euphausiacea), with particular reference to swarming behavior and the size and proximity of the predator. J Crustac Biol 7:449-457

Pauly T, Nicol S, Higginbottom I, Hosie G, Kitchener J (2000) Distribution and abundance of Antarctic krill (Euphausia superba) off East Antarctica (80-150 $\left.{ }^{\circ} \mathrm{E}\right)$ during the Austral summer of 1995/1996. Deep-Sea Res II 47:2465-2488

Pollard R, Sanders R, Lucas M, Statham P (2007) The Crozet natural iron bloom and EXport experiment (CROZEX). Deep-Sea Res II 54:1905-1914

Reid K, Sims M, White RW, Gillon KW (2004) Spatial distribution of predator/prey interactions in the Scotia Sea: implications for measuring predator/fisheries overlap. DeepSea Res II 51:1383-1396

Ricketts C, Watkins JL, Priddle J, Morris DJ, Buchholz F (1992) An assessment of the biological and acoustic characteristics of swarms of Antarctic krill. Deep-Sea Res I 39:359-371

Ringelberg J (1995) Changes in light intensity and diel vertical migration: a comparison of marine and freshwater environments. J Mar Biol Assoc UK 75:15-25

Ritz D (1994) Social aggregations in pelagic invertebrates. Adv Mar Biol 30:155-216

Ritz DA (2000) Is social aggregation in aquatic crustaceans a strategy to conserve energy? Can J Fish Aquat Sci 57: $59-67$

Ross RM, Quetin LB, Lascara CM (1996) Distribution of Antarctic krill and dominant zooplankton west of the Antarctic Peninsula. In: Ross RM et al. (ed) Foundations for ecological research west of the Antarctic Peninsula. AGU Antarctic research series. American Geophysical Union, Washington, DC, p 199-217

Siegel V (2000) Krill (Euphausiacea) demography and variability in abundance and distribution. Can J Fish Aquat Sci 57:151-167

Sprong I, Schalk PH (1992) Acoustic observations on krill spring-summer migration and patchiness in the Northern Weddell Sea. Polar Biol 12:261-268

Staniland IJ, Boyd IL (2003) Variation in the foraging location of Antarctic fur seals (Arctocephalus gazella) and the effects on diving behavior. Mar Mamm Sci 19:331-343

Tarling GA, Johnson ML (2006) Satiation gives krill that sinking feeling. Curr Biol 16:R83-R84

Tarling GA, Klevjer T, Fielding S, Watkins JL and others

Editorial responsibility: Hans Heinrich Janssen,

Oldendorf/Luhe, Germany
(2009) Variability and predictability of Antarctic krill swarm structure. Deep-Sea Res I 56:1994-2012

Thomasson MA, Johnson ML, Strömberg JO, Gaten E (2003) Swimming capacity and pleopod beat rate as a function of sex, size and moult stage in Northern krill Meganyctiphanes norvegica. Mar Ecol Prog Ser 250: 205-213

Thorpe SE, Heywood KJ, Stevens DP, Brandon MA (2004) Tracking passive drifters in a high resolution ocean model: implications for interannual variability of larval krill transport to South Georgia. Deep-Sea Res I 51:909-920

Thorpe SE, Murphy EJ, Watkins JL (2007) Circumpolar connections between Antarctic krill (Euphausia superba Dana) populations: investigating the roles of ocean and sea ice transport. Deep-Sea Res I 54:792-810

> Trathan PN, Everson I, Miller DGM, Watkins JL, Murphy EJ (1995) Krill biomass in the Atlantic. Nature 373:201-202

> Trathan PN, Brierley AS, Brandon MA, Bone DG and others (2003) Oceanographic variability and changes in Antarctic krill (Euphausia superba) abundance at South Georgia. Fish Oceanogr 12:569-583

Veit RR, Hunt GL (1991) Broadscale density and aggregation of pelagic birds from a circumnavigational survey of the Antarctic Ocean. Auk 108:790-800

> Veit RR, Silverman ED, Everson I (1993) Aggregation patterns of pelagic predators and their principal prey, Antarctic krill, near South Georgia. J Anim Ecol 62:551-564

Watkins JL, Brierley AS (1996) A post-processing technique to remove background noise from echo integration data. ICES J Mar Sci 53:339-344

Watkins JL, Brierley AS (2002) Verification of the acoustic techniques used to identify Antarctic krill. ICES J Mar Sci 59:1326-1336

> Woodd-Walker RS, Watkins JL, Brierley AS (2003) Identification of Southern Ocean acoustic targets using aggregation backscatter and shape characteristics. ICES J Mar Sci 60:641-649

> Zamon JE, Greene CH, Meir E, Demer DA, Hewitt RP, Sexton $S$ (1996) Acoustic characterization of the three-dimensional prey field of foraging chinstrap penguins. Mar Ecol Prog Ser 131:1-10

Zhou M, Dorland RD (2004) Aggregation and vertical migration behavior of Euphausia superba. Deep-Sea Res II 51: 2119-2137

Submitted: October 7, 2009; Accepted: March 25, 2010 Proofs received from author(s): June 2, 2010 